\title{
Kerguelen Plateau volcanism linked to the early Cretaceous Oceanic Anoxic Event 1a
}

\author{
Q. JIANG ${ }^{1}$, F. JOURDAN ${ }^{1}$, H.K.H. OLIEROOK ${ }^{1}$, R.E.
} MERLE $^{2}$

${ }^{1}$ Curtin University, Perth, GPO Box U1987, WA, Australia. qiang.jiang1@postgrad.curtin.edu.au

${ }^{2}$ Swedish Museum of Natural History, S-104 05 Stockholm, Sweden

The early Cretaceous oceanic anoxic event (OAE) 1a represents one of the greatest climate and ecosystem perturbations of the Phanerozoic, as evidenced by global deposition of organic carbon-rich black shales, large carbonisotope anomalies, and negative excursions in the ${ }^{87} \mathrm{Sr} /{ }^{86} \mathrm{Sr}$ and ${ }^{187} \mathrm{Os} /{ }^{188} \mathrm{Os}$ records. Due to their apparent synchronicity, it is generally believed that such an extreme state of the oceanic system might have been caused by the emplacement of the Ontong Java Plateau, the volumetrically largest igneous province (LIP) of the Phanerozoic. Despite of being the second largest LIP, the Kerguelen Plateau, however, yielded radioisotopic ${ }^{40} \mathrm{Ar} /{ }^{39} \mathrm{Ar}$ ages all younger than $121 \mathrm{Ma}$ [1] and thus has not been recognized as a contributor to the occurrence of OAE 1a which current best estimates suggest an age of $\sim 122 \mathrm{Ma}$ [2]. Here, we report 9 new fresh plagioclase ${ }^{40} \mathrm{Ar} /{ }^{39} \mathrm{Ar}$ plateau ages of basalt samples from the upper stratigraphic level of the Southern Kerguelen Plateau. The new age data range from $127.9 \pm 1.8 \mathrm{Ma}$ to $121.2 \pm 2.1$ $\mathrm{Ma}$, indicating that the bulk of the Southern Kerguelen Plateau was emplaced slightly before or coeval with the OAE 1a. The suggests that the Southern Kerguelen Plateau volcanism may have played a significant role in the occurrence of OAE 1a and greatly affected the environment and ecosystem at that time, perhaps in conjunction with the Ontong Java LIP.

[1] Duncan, (2002). J. Petrol. 43, 1109-1119.

[2] Olierook et al. (2019). Earth-Sci. Rev. 197, 102906. 